\title{
Street Vending, Income Generation and Poverty Implication: The Case of the Kathmandu Valley, Nepal
}

\author{
Kumar Bhattarai ${ }^{1 *} \odot$, Balaram Pathak ${ }^{1}$ (])
}

\author{
Department of Economics, Patan \\ Multiple Campus, Tribhuvan \\ University, Nepal \\ * Corresponding Author \\ (bhattarai1000@gmail.com)
}

Received: 10 June, 2020

Revised: 28 July, 2020

Accepted: 08 October, 2020

Published: 15 December, 2020

How to cite this paper: Bhattarai, K., \& Pathak, B. (2020). Street vending, income generation and poverty implication: The case of the Kathmandu Valley, Nepal. Quest Journal of Management and Social Sciences, 2(2), 194-205.

Copyright (C) 2020 by authors and Quest Journal of Management and Social Sciences.

This work is licensed under a Creative Commons Attribution-Non Commercial-No Derivatives 4.0 International License.

https://creativecommons.org/

licenses/by-nc-nd/4.0/

\begin{abstract}
Background: Street vending, like other informal activities, contributes to employment generation. For many people, it is a source of income and thus has a poverty implication for street vendors.
\end{abstract}

Objective: The major objective of this study is to analyze street vending, income generation and poverty implication in the Kathmandu Valley, Nepal. The specific objectives are: to measure the net business income of street vendors, to determine factors influencing street vendors' net business income and to analyze the poverty implication of street vending in the Kathmandu Valley.

Methods: The study was based on the analytical approach, where the net business income of street vendors was measured, factors influencing net business income of street vendors were determined and the potential role of street vending on poverty reduction in Kathmandu Valley was analyzed. Factors influencing net business income of street vendors were identified by applying regression analysis. For this, cross-sectional data were collected from randomly selected 450 street vendors of five locations of the Kathmandu Valley, i.e. Balaju, Lagankhel, Kalanki, Ratnapark and Suryabinayak. Data were collected using a structured questionnaire. The poverty implication of street vending was analyzed by using the consumption approach, where measurement was done about whether consumption of street vendors, which was covered by their net business income, was above the poverty line of the Kathmandu Valley.

Results: Average monthly net business income of street vendors was Rs 22,500. Educational level, experience, sales and working hours per day were the factors influencing net business income of street vendors. 54\% of street vendors were found to have consumption above the poverty line which was covered by their net business income. Furthermore, it was found that if respondents were not involved in street vending; only $42 \%$ of respondents could have consumption above the poverty line which could be covered by their income from other jobs/professions.

Conclusions: The study concludes that majority of people, who do street vending in the Kathmandu Valley, come from low income family background. Street vending plays an important role to provide employment to the people belonging to socially and economically marginalized groups of the society. However, at the same time, street vending also creates problems like overcrowding on the roadsides, environmental pollution due to the generation of waste during street vending, and so on. So, the focus should be on shifting street vendors to the formal sectors in the long-term.

Implications: As street vending is a source of income for thousands of socially and economically mariginalized groups and has poverty implications, it should not be viewed just as a problem of the street. If it is managed properly, it contributes to the livelihood of thousands of people and provides goods and services at a cheaper price to low-income consumers.

Keywords: Street vending, Net business income, Kathmandu Valley, Poverty

Paper Type: Research paper

JEL Classifications: J47, O12, O17 


\section{Introduction}

In many developing and least developed countries like Nepal, a significant portion of employed people are involving in the informal sector (Central Bureau of Statistics [CBS], 2008). Street vending is the most visible expression of the informal sector (Onodugo et al., 2016). According to the official statistics of African, Asian, and Latin American cities, street vendors make up between 2 to 24 percent of total urban informal employment (Roever, 2014). Street vendors are an important part of the urban economy throughout the world, offering easy access to many goods and services to the consumers in public places (Women in Informal Employment: Globalizing and Organizing [WIEGO], 2014). Studies show that when street vendors are allowed to conduct their trade, it has a positive effect on poverty reduction, employment generation, entrepreneurship, social mobility, peace and order, and democratization of resources between men and women (Kusakabe, 2006). Street vending involves selling cheap goods on the sidewalk to large street restaurants that employ a dozen people (Batreau \& Bonnet, 2016; Bhowmik, 2005; Brata, 2008).

In Nepal, street vendors sell many goods, like fresh vegetables, prepared foods, consumer electronics, clothes, cosmetics, building materials, utensils, etc., which many consumers, especially low-income consumers, prefer over retail outlets and shopping malls as street vendors provide goods at a relatively inexpensive price. So, street vending has a dual role in Nepalese urban areas: providing employment opportunities to many urban low-income unemployed people as well as migrated people from rural areas and providing goods at a relatively cheaper price to many, mainly, low-income consumers. With the increasing urbanization in Nepal, street vending is also increasing in all urban areas including the Kathmandu Valley. Street vendors can be seen in almost all parts of the city areas of the Kathmandu Valley. Low entry barriers, flexible working time, inadequate opportunities to work in the formal sector, failure on other businesses, lack of adequate skill to work in the formal sector and disability are the major factors behind engaging people in street vending.

Studies suggest that street vendors encounter excessive policing (Anjaria, 2006; Bhowmik, 2005; Cross, 2000; Devlin, 2011; Yatmo, 2014; Batreau \& Bonnet, 2016). Street vendors are running their businesses in a vulnerable situation in the Kathmandu Valley, like lack of institutional credit facility, harassment from police, the problem of damaging goods by vehicles and pedestrians, paying money to police to avoid harassment, paying money to local gangs and giving donations to the sister organizations of different political parties.

Least developed countries, like Nepal, are facing problems of massive unemployment. Unemployment is one of the reasons behind poverty. One of the macroeconomic policy objectives of the government of Nepal is to reduce poverty (National Planning Commission [NPC], 2019). For this, the income of the people should increase, which is possible by generating employment opportunities or encouraging selfemployment. Street vending is one of the potential areas in the informal sector that may have poverty implications. In this context, this study has three objectives: to measures the net business income of street vendors, to determine factors influencing net business income of street vendors and to analyze the poverty implication of street vending in the Kathmandu Valley.

Various studies are conducted, in different countries, on the issues of street vendors. Bernal-Torres et al. (2020) studied street vendors in Bogota, Colombia by employing a qualitative approach. Researchers interviewed 50 vendors having at least 2 years' of experience in vending by applying a semi-structured interview. Study has found that respondents were involved in street vending due to a lack of employment opportunities in other sectors. It was the only source of income for the vendors. Even though there is no social prestige of street vendors in Bogota as they are viewed as nobody and are ignored, scorned and disqualified as people by the society, they had a positive vision regarding their work as something decent activity. Igudia (2019) explored the theories, determinants and policy options of street vendors in Lagos state, Nigeria by using the demand-side approach. Data were collected in a two-stage process: 
first, by street-by-street survey; and second, by a purposeful selection of 600 respondents. Multinomial logistic regression was applied for the determination of factors underpinning demand for street vending. Researcher found that formal economy failures, social/redistributive explanations and financial gains are the factors determining the demand for street vending in Nigeria. Truong (2018) analyzed the role of street vending on poverty reduction in Hanoi, Vietnam. Study was conducted by taking a sample of 67 street vendors. For this, a systematic stratified sampling technique was applied. The analysis was based on a qualitative approach, where semi-structured interviews were conducted with street vendors at four tourist sites of Hanoi. Both mobile and fixed street vendors were interviewed. Researcher found that major reasons behind street vending were low farm output, limited farmland, decline of non-farm job and family-related issues including death of a husband of female street vendors and burning down of their houses on fire. The most critical challenge faced by street vendors was the government's ban on street vending on tourist sites, which reduced their incomes. Police officers were used to patrol tourist sites. However, such a ban was not working as vendors were ableto avoid the security team by learning about its patrol time. Researcher concludes, by giving different examples of respondents, that street vending increased the income of people above the international poverty line.

Martinez, Short, and Estrada (2017) analyzed experiences of street vendors in Cali, Colombia by taking a randomly selected sample of 527 street vendors. Compared with the rest of Cali's working population, street vendors were found to be less educated, had worked longer hours, and were more likely than the general population to be disabled or from an indigenous backward society. More than two-thirds of vendors were found to be heads of households, which shows that street vending is the central part of a household's domestic economy. Study found a high level of satisfaction among the street vendors in Cali. 93\% of street vendors were not interested to sell their business. Street vending was found to be operating alongside the stores and businesses of the formal sector. Thus, street vendors and formal stores were together providing retail opportunities for shoppers, differentiated by price and quality but collectively providing a complex retail space. Goods and services, as well as knowledge, were found to be shared and transmitted across formal and informal vendors. Street vendors were found to be purchasing goods from the formal economy. Thus, there was the economic linkage between street vendors and the formal economy.

Mazhambe (2017) analyzed the contribution of street vending on living standard of street vendors in Harare, Zimbabwe. For this, a cross-sectional survey was conducted by taking a sample of 166 street vendors. The result showed that $86.6 \%$ of street vendors depended entirely on street vending as their source of income. Furthermore, the major reasons behind street vending were lack of alternative employment opportunities, to ensure household food security, and to supplement the income from other activities. The study found that $45.36 \%$ of the respondents were involved in street vending for a period of more than six years, showing that street vending was a reliable source of income for the people. $69 \%$ of the respondents were found to have made a daily profit of less than $\$ 10$. Similarly, $26 \%$ of the respondents were making daily profit in between $\$ 10$ to $\$ 20$ whereas $5 \%$ were making a daily profit of somewhere between $\$ 21$ to $\$ 40$. The study concludes that street vending has a contribution in improving the living standards of street vendors. Researcher suggests to assign particular areas as vending zones.

Onodugo et al. (2016) analyzed street vending in Enugu city, Nigeria by applying qualitative survey method. Data were collected by administering two sets of questionnaires, one set for street vendors and another set for urban planners by employing the systematic random sampling technique. The study suggests that stopping street vendors from doing their business is not an effective way of managing street vending as it results in loss of jobs and means of livelihood of vendors. Similarly, it negatively affects the dependents of street vendors. Researchers suggest for the change in existing policy related to street vending in Enugu state. Roever and Skinner (2016) synthesized research and evidence on urban policies and local government practices concerning street vending. The study presents evidence on the 
size, composition and contribution of street vending and reviews the literature on street vending as well as media coverage that reflect the extent of exclusionary policies and practices. Researchers conclude that street vending contributes not only to the self-employment of street vendors but also contributes in generating demand for a wide range of services provided by other informal workers, like transport workers, tea sellers, market porters, etc. as well as generates demand for services provided by the formal sector public and private actors, like transportation and formal shops and suppliers from whom they source their goods.

Chauke, Munzhelele, and Maiwashe (2015) analyzed the factors influencing street sellers' ability to generate income above the poverty line in the Vhembe district of South Africa. Data were collected from randomly selected 132 street vendors of four local municipalities of the Vhembe district by using a semi-structured questionnaire. The analysis was conducted using logistic regression. Researchers found that investment in stock purchases, monthly income, and profit had a positive impact on generating income above the poverty line whereas challenges faced by street vendors and business activity had a negative impact.

The city dwellers, in the Kathmandu Valley, are much more concerned about negative aspects of street vending, like using the street pavement, creating traffic problems and throwing waste on public places. However, there are also positive implications of street vending to society, like generating employment opportunities and providing inexpensive goods and services to the low-income consumers. In such a situation, it is important to know its possible role in income generation and its poverty implication. Despite increasing street vending in the Kathmandu Valley (and in other parts of Nepal), the empirical studies on its poverty implication are either scanty or non-existent. The result of this study might be useful to the researcher as well as policymakers.

The remaining part of this paper consists of three sections. The second section provides methodology. This section describes the research design and sampling techniques employed, analytical model, questionnaire design, and data collection. The third section considers data analysis and results and the fourth section concludes.

\section{Research Method}

\section{Research Design, Study Area, Sampling Method and Sample Size}

This study employed an analytical approach, where the net business income of street vendors was measured, factors influencing net business income of street vendors were determined and the potential role of street vending on poverty reduction in the Kathmandu Valley was analyzed. For this, a survey was conducted, where 450 street vendors were interviewed. To collect data, a structured questionnaire was developed and this was administered in five locations of the Kathmandu Valley, namely Balaju, Lagankhel, Kalanki, Ratnapark and Suryabinayak. These locations were chosen because these are some of the locations where a significant number of street vendors do their businesses in the Kathmandu Valley. In each of Balaju and Lagankhel, 105 street vendors were interviewed whereas, in each of Kalanki, Ratnapark and Suryabinayak, 80 street vendors were interviewed. Thus, the study was mainly based on primary sources of data. However, depending upon the necessity of study, secondary sources of data, like reports published by government and private agencies and research articles were also used. Interview of randomly selected street vendors was taken. As there was no sampling frame of street vendors, the enumerators went to each of the locations and interviewed each of every fourth street vendor that they met. In the situation of not accepting interviews by the selected 4th respondent, the immediate next respondent was approached. This method is expected to be helpful to ensure the random selection of interviewees in the study. 


\section{Analytical Model}

Various researchers have applied regression analysis on the studies related to street vending, where different variables were taken into consideration (Chauke et al, 2015; Kathuria \& Raj, 2015). This study also employed regression analysis to model the relationship between explanatory variables (i.e. the educational level of respondents, working hours per day,experience of respondent, and sales per month), and net business income of street vendors in the Kathmandu Valley as shown in equation (1).

$\operatorname{lnNBI}=\alpha+\beta_{1}$ Education $+\beta_{2}$ Experience $+\beta_{3} \ln$ Sales $+\beta_{4}$ Working hours $+\mathrm{u}$

Where,

$\mathrm{NBI}=$ Net business income per month, which is equal to TR-TC

TR is the total revenue per month whereas TC is the total cost per month

Education $=$ Educational level of respondent, which was classified into five categories, i.e. no degree attained, secondary education, higher secondary education, bachelor degree, and master's degree

Experience $=$ Experience of the respondent in street vending measured in no. of years

Sales $=$ Sales per month

Working hours $=$ Working hours per day

$\mathrm{u}=$ Error term

$\alpha$ is the constant and $\beta_{1}, \beta_{2}, \beta_{3}$ and $\beta_{4}$ are the coefficients of explanatory variables

It should be noted that $\mathrm{TC}$ is a sum of accounting and implicit costs. Accounting cost is the payment made by street vendors to purchase the necessary goods and services which are later on used in street vending. It involves a total fixed cost (TFC) and total variable cost (TVC). On the other hand, the implicit cost is the street vendor's opportunity cost of involvement in street vending, which is equal to the income that could be earned from the next best alternative to street vending.

Thus, TC $=$ TFC + TVC + Implicit Cost

Total fixed cost per month was computed by dividing the cost of fixed input by lifetime of input in terms of the month. Furthermore, TR is the income earned from street vending.

\section{Survey and Questionnaire Design}

Data were collected by using a structured questionnaire. Before preparing the questionnaire, a scoping survey was conducted. From the information obtained from the scoping survey, the draft questionnaire was prepared, which was pre-tested in a pilot survey of 15 street vendors of Balaju, Lagankhel, Kalanki, Ratnapark and Suryabinayak. On the basis of the result and the feedback of the pilot survey, the questionnaire was finalized, which was later administered to randomly selected 450 street vendors.

There were three sections in the questionnaire. The first section was 'identification of respondent', which contained the questions related to the name, contact number and the address of the respondent. The second section was 'information regarding the business of street vendor'. This section contained questions related to mobile or fixed vending, the period of time they were involving in street vending per day and per week, last week's expenditure on goods and services purchased for vending, last week's household expenditure of respondent, and so on. The last section was 'socio-economic and demographic information of respondent'. In this section, questions were related to age, educational attainment, marital status, household size and sex of the respondent.

\section{Data Collection}

Data were collected between May 02- June 15, 2019. For this, two enumerators were hired and trained. Among these enumerators, one had already completed master's degree in economics whereas another was writing a thesis of master's degree in economics. The analytical model was estimated to identify 
the factors influencing street vendors' net business income. Data were analyzed by using the software package STATA 13.0.

\section{Data Analysis and Result}

\section{Socio-economic and Demographic Features of Respondents}

Among the respondents, $40.89 \%$ were male whereas $59.11 \%$ were female. Thus, most of the street vendors were female. The average age of the respondent was 44 years. The eldest street vendor was of 84 years whereas the youngest was of 17 years. Among 450 respondents, 310 were found not to have any educational degree whereas 128 respondents had secondary education, 10 respondents had higher secondary education and 2 respondents had a bachelor's degree. There were no respondents who had an educational degree above a bachelor's level. Thus, $68.89 \%$ of the respondents had no educational degrees. The study suggests that mostly those people who had no formal education and hence had lower opportunities in alternative jobs in the formal sectors of the economy were found to be involved in street vending in the Kathmandu Valley.

Most of the respondents were married (89.11\%). Only $10.89 \%$ were unmarried. The average size of the households was 5 . The largest household size was 11 whereas the smallest was 1 .

Table 1: Socio-economic and demographic features of respondents

\begin{tabular}{ll}
\hline Variable & Respondents \\
\hline Sex & $184(40.89 \%)$ \\
Male & $266(59.11 \%)$ \\
Female & \\
Age (Years) & 44 \\
Average age & 84 \\
Highest age & 17 \\
Lowest age & \\
Educational Level & $310(68.89 \%)$ \\
No degree attained & $128(28.44 \%)$ \\
Secondary education & $10(2.22 \%)$ \\
Higher secondary education & $2(0.44 \%)$ \\
Bachelor degree & \\
Marital Status & $401(89.11 \%)$ \\
Married & $49(10.89 \%)$ \\
Unmarried & \\
Size of Household & 5 \\
Average size & 11 \\
Largest size & 1 \\
Smallest size & \\
Monthly household expenditure (Rs) & 57,000 \\
Maximum monthly expenditure & 8,200 \\
Minimum monthly expenditure & 26,200 \\
Average monthly expenditure & \\
&
\end{tabular}




\section{Permanent place of residence}

Kathmandu valley $18 \%$

Out of Kathmandu valley $82 \%$

Source: Authors' computation from survey data, 2019

The average monthly household expenditure was Rs 26,200. The highest monthly expenditure was Rs 57,000 whereas the lowest was Rs 8,200. Questions were asked to the respondents regarding their permanent place of residence. The study has found that most of the respondents $(82 \%)$ were from out of the Kathmandu Valley. Only 18\% were from the Valley.

\section{Types of Street Vendors and Reasons behind Street Vending}

Street vendors may be mobile or fixed. Some vendors may combine both fixed and mobile vending. However, this study has found only mobile and fixed vendors. $82 \%$ of the respondents were fixed vendors whereas $18 \%$ were mobile vendors.

\section{Figure 1: Fixed and mobile vendors}

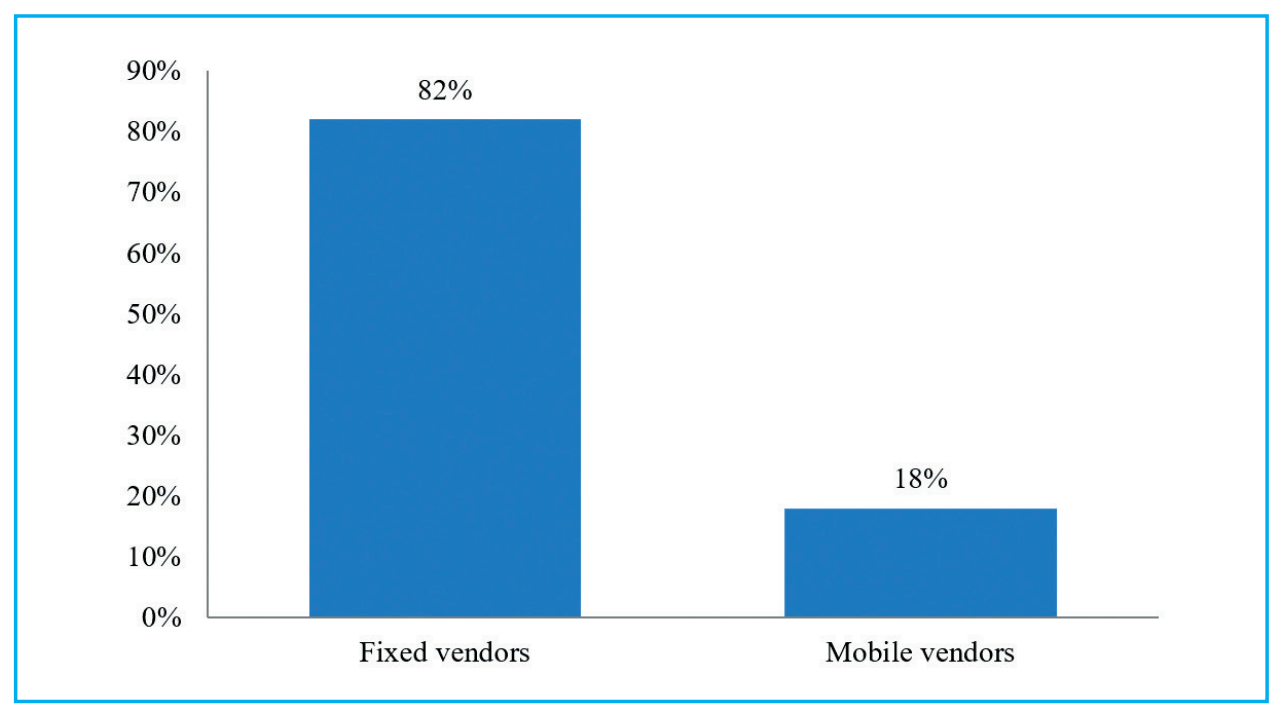

Source: Field survey, 2019

Question was asked about why they chose street vending. The respondents gave various reasons for their choices. Lack of skills to work in formal sectors, lack of financial capital to make investments in other sectors, having sufficient income in street vending, being disabled, being a farmer, etc. were the reasons given by the respondents. Reasons given by the respondents, in their own words, were as follows:

- It is easy to start street vending as it requires less amount of investment. I do not have sufficient financial capital to do other businesses.

- Initially, I had started my profession through street vending but later on, I could not change the profession. I am involving in this profession as I am not able to get an alternative job.

- It's my seasonal business. I am involved in this business during the spring season but in the summer season I go to my village to be involved in agriculture.

- I am not educated and thus I do not have the skills to work in the formal sector.

- I am a farmer. I produce vegetables on my own land and bring them here to sell. I do not have any other occupation. 
- In the past, I did other works (like a retail shop) but unfortunately it was not successful. Thus, street vending became the last alternative to me.

- I have a good income in this occupation. So, I did not want to change it.

- I am disabled so that I cannot get other jobs.

\section{Types of Goods Sold by Street Vendors}

A variety of goods and services were found to have sold by street vendors: food, fruits, clothes, cigarette, noodle, paan, chhurpi (a traditional cheese product, which is produced in Nepal), betel nut, shoes, second-hand shoes, bag, bottled water, ice-cream, carbonated water, lemonade, toothbrush, and so on. The services that some street vendors provided were watch and mobile repairing, shoe polishing, tailoring, and so on. These goods and services are classified into eight categories, namely clothes, consumer electronics, utensils, food, fruits, vegetables, service and other items. The category 'other items' included cigarette, chewing gum, wallet, bag, bottled water, carbonated water, etc. that are not included in the earlier seven categories. Figure 2 shows the percentage of street vendors selling these items.

\section{Figure 2: Street vendors selling different items (percentage)}

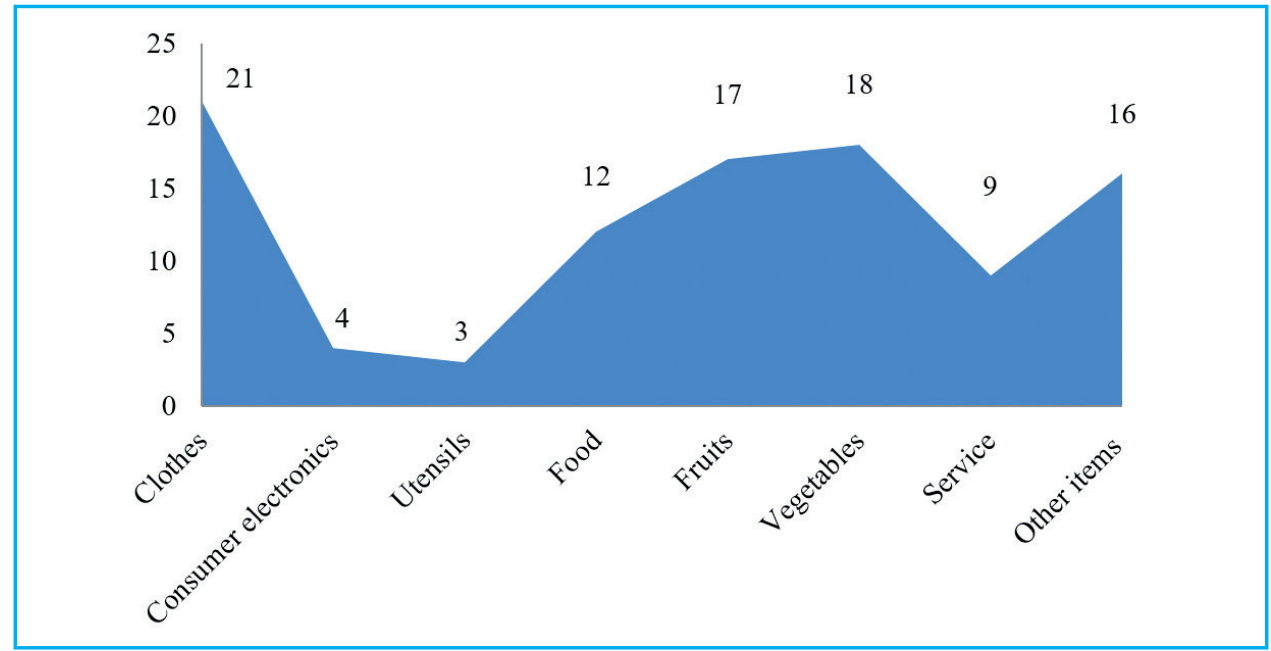

Source: Field survey, 2019

\section{Time Spent on Street Vending}

Venders were, on average, found to be working 8 hours per day. Similarly, vendors were working, on average, 6 days per week. At the maximum level, they were working 7 days per week whereas at the minimum level they were working 3 days per week. The study found that there was a wide range of variations in the experience of street vending. The vendors having the highest level of experience were working in this occupation for the last 40 years, whereas vendors having the lowest level of experience were working for the last one month. On average, street vendors had the experience of 15 years. This level of average experience of vendors suggests that street vending is a reliable occupation for them. If it was not reliable, vendors would not have such stability in their occupation.

\section{Level of Satisfaction in Street Vending}

Question was asked to the street vendors regarding their level of satisfaction from their occupation. For this, three options regarding level of satisfaction were provided to the respondents, i.e. high, moderate and low. The study found that $19 \%$ had a high level of satisfaction. Similarly, $41 \%$ had moderate satisfaction whereas $40 \%$ had a low level of satisfaction. 
Figure 3: Level of satisfaction in street vending

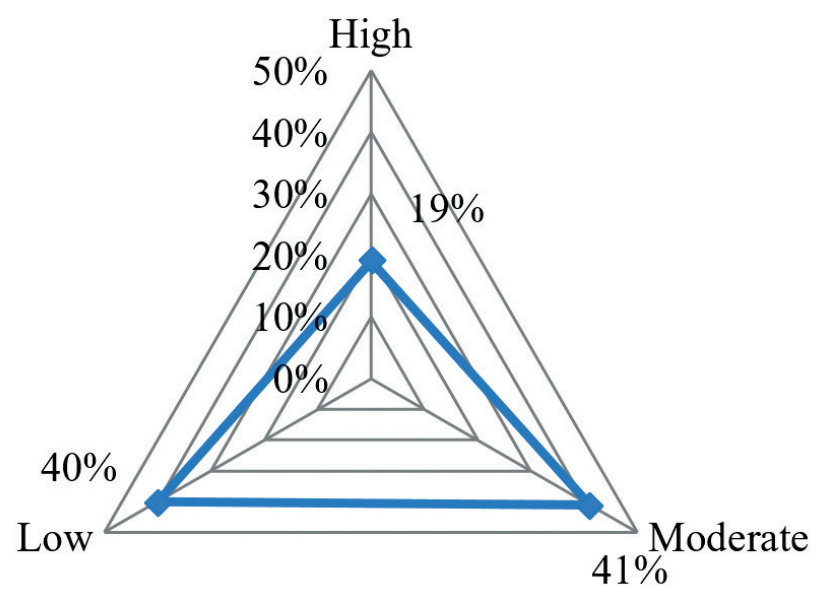

Source: Field survey, 2019

Those vendors who had a high level of satisfaction said that they have a good income from street vending. Respondents who had moderate satisfaction said that income from street vending is sufficient to manage household expenditure including health and education expenses of their children. Respondents showing a low level of satisfaction opined that there was a low level of income from their occupation and there is always conflict with municipality police during their business and the working environment is very poor in street vending.

\section{Net Business Income of Street Vendors}

The net business income of vendors varied according to the items sold by them. The study found that the highest average net business income was of clothes sellers followed by vegetable sellers, fruits sellers, consumer electronics sellers, food sellers, utensils sellers, service sellers and sellers of other items. The minimum net business income was Rs 5,570 per month whereas the maximum net business income was Rs 51,560 per month. The average net business income was Rs 22,500 per month. Thus, there was a wide range of variation in the net business income of street vendors.

Table 2: Net business income of street vendors

\begin{tabular}{lcc}
\hline \multicolumn{1}{c}{ Item } & Respondents (Percentage) & $\begin{array}{c}\text { The average net business income } \\
\text { per month (Rs) }\end{array}$ \\
\hline Clothes & 21 & 26,290 \\
Consumer electronics & 4 & 18,243 \\
Utensils & 3 & 16,931 \\
Food & 12 & 17,200 \\
Fruits & 17 & 19,540 \\
Vegetables & 18 & 21,124 \\
Service & 9 & 13,527 \\
Other Items & 16 & 12,599 \\
\hline
\end{tabular}

Source: Field survey, 2019 
The study analyzed the factors influencing the net business income of street vendors. For this, the analytical model (1) was estimated. The distribution of residuals was also checked by applying the Shapiro-Wilk W test. The p-value was 0.71523 , which shows that we can accept the null hypothesis that residuals are normally distributed. Similarly, the heteroskedasticity of residuals was checked by applying the Breusch-Pagan test. The p-value was 0.9025, which shows that we can accept the null hypothesis of homoscedasticity of residuals.

The multicollinearity among the explanatory variables was tested by estimating the variance inflation factor (VIF). As the VIF values, for each variable, were less than 10, there was no multicollinearity among the explanatory variables.

The result of regression analysis is shown in table 4 . The F-statistic was highly significant $(\mathrm{p}=0.0000)$. R-Squared was 0.2146. Thus, the analytical model was well-fitted.

Table 3: Result of regression analysis

\begin{tabular}{lcc}
\hline Variable & Coefficient & Standard error \\
\hline Constant & 4.179326 & 0.729376 \\
Education & $.012793 * * *$ & .002996 \\
Experience & $.032475 * * *$ & .009046 \\
lnSales & $.563792 * * *$ & .134557 \\
Working hours per day & $.036247 * * *$ & .011507 \\
\hline
\end{tabular}

$* * * \mathrm{p}<0.01$

Clearly, the result of regression analysis suggests that educational level, experience of respondents, sales per month and working hours per day were the factors influencing the net business income of street vendors. The educational level had a positive and significant effect $(p<0.01)$ on net business income. The study found that one more level of education increased net business income by 1.28 percent. Experience in street vending had also a positive and significant effect $(p<0.01)$ on net business income. Analysis suggests that an increase in experience by one year led to an increase in net business income by $3.25 \%$. Sales was found to have a positive and significant effect $(p<0.01)$ on net business income. The result shows that $1 \%$ increase in sales led to a 0.56 percent increase in net business income. Finally, working hours per day has a positive and significant effect on the net business income of street vendors. Result suggests that an increase in vending by one hour per day led to an increase in net business income by $3.62 \%$.

\section{Poverty Implication of Street Vending}

The measurement of poverty in Nepal is based on the cost of basic needs approach. According to this approach, the poverty line is defined as a level of expenditure by individuals, which is necessary to fulfill basic needs in terms of both food and non-food items (CBS, 2011). An analysis was done on whether the consumption of street vendors was above the poverty line of the Kathmandu Valley. The latest poverty measurement of Nepal was based on data of the third round of Nepal living standard survey (NLSS-III), which was conducted in 2010-2011. According to that survey, the poverty line in Kathmandu was defined as Rs 40,933 per year (CBS, 2011). NLSS-III was conducted in 2010-2011 whereas this study was conducted in 2019; the poverty line was adjusted as per the rate of inflation in this period. So, the adjusted poverty line is Rs 64,388 per year as the rate of inflation in the period of 2011-2018 was $57.3 \%$.

To get information on street vendor's consumption expenditure, the goods and services were classified into three categories, i.e. food items, non-food items and consumption of housing (rent per month). Food items and non-food items were further classified into several sub-items. Then, a question was asked to the street vendors regarding his/her family's last week's expenditure on those goods and services, which was later on used to generalize for monthly and then yearly household consumption 
expenditure. Afterward, yearly individual consumption expenditure was computed by dividing yearly household consumption expenditure by respective household size. To identify the possible role of street vending on poverty reduction, a computation was made on how many vendors' yearly individual consumption expenditure was above the poverty line that was covered by their yearly net business income from street vending. It was also computed how many of those vendors could have yearly individual consumption expenditure above the poverty line if they were not involved in street vending. It should be noted that in case of those vendors who got support from the family member(s), those family members' contribution was also deducted to find vendors' yearly net business income (for the purpose of measuring the role of street vending on poverty reduction of the street vendor).

Among 450 respondents, the study found that 243 (54\%) respondents had consumption above the poverty line that was covered by their net business income. Similarly, data suggest that if those respondents were not involved in street vending; only $189(42 \%)$ respondents could have consumption above the poverty line whose consumption would be covered by their income from other jobs/ professions. The earning that respondents could have earned if they had not been involved in street vending was calculated through questions about how much amount they could earn in the next best alternative job/profession. Thus, the study found that $12 \%$ of additional vendors were able to come out from absolute poverty due to their involvement in street vending. Hence, it can be concluded that street vending contributed to the vendors coming out from absolute poverty in the Kathmandu Valley. Truong (2018) also found that street vendors enhanced their living standards from street vending in Hanoi, Vietnam.

\section{Conclusion}

This study measured the net business income of street vendors, determined factors influencing net business income of street vendors and analyzed poverty implications of street vending in the Kathmandu Valley, Nepal. The study was conducted by taking a randomly selected 450 street vendors from five locations of the Kathmandu Valley, i.e. Balaju, Lagankhel, Kalanki, Ratnapark and Suryabinayak. It was found that clothes sellers had the highest level of monthly net business income (Rs 26,290) followed by vegetable sellers (Rs 21,124), fruit sellers (19,540), consumer electronics sellers (Rs 18,243), food sellers (Rs 17,200), utensils sellers (Rs 16,931), service sellers (Rs 13,527) and sellers of other items (Rs 12,599). Educational level, the experience of respondents, sales per month and working hours per day were the factors influencing net business income of street vendors in the Kathmandu Valley. Street vending was found to have contributed to come out the street venders from absolute poverty in the Kathmandu Valley.

However, at the same time, street vending is creating some problems in the city areas. For example, it is creating a traffic problem on the road, which can be reduced by allowing street vending on specific periods of time of the day. The period of time should be chosen in such a way that there is less movement of people and vehicles on the road. Similarly, street vendors throw garbage on the road. This problem can be solved if street vendors are made responsible for the waste material created so that they manage the garbage themselves. Thus, there is a necessity of proper management of street vending. It should not be viewed just as a problem of the street. If managed properly, it will be one of the instruments for improving the livelihood of thousands of poor and unskilled people of the country.

However, the long-term solution is to shift street vendors to the formal sector. If they could get support from the government and have access to institutional credit, they can be shifted to formal sector. As they already have certain level of entrepreneurship, they can use this skill to upgrade their business and livelihood. Such shifting to the formal sector may provide employment opportunities to other people (as they might hire workers for their business) whereas the government may collect more tax revenue. This might be helpful to reduce the size of the informal economy and to solve the problems created by street vending in the Kathmandu Valley as well as other city areas of the country. 


\section{Conflict of Interest}

There was no conflict of interest while preparing this article.

\section{References}

Anjaria, J. S. (2006). Street hawkers and public space in Mumbai. Economic and Political Weekly, 41(21), 21402146. http://www.jstor.org/stable/4418270

Batreau, Q., \& Bonnet, F. (2016). Managed informality: Regulating street vendors in Bangkok. City and Community, 15(1), 29-43. http://dx.doi.org/10.1111/cico.12150

Bernal-Torres, C.A., Peralta-Gomez, M. C., \& Thoene, U. (2020). Street vendors in Bogota, Colombia, and their meanings of informal work. Cogent Psychology, 7(1), 1-14. http://dx.doi.org/10.1080/23311908.2020.17 26095

Bhowmik, S. K. (2005). Street vendors in Asia: A review. Economic and Political Weekly, 40, 22-23. http://old. alnap.org/pool/files/bhowmik-street-vendors-in-asia.pdf 2256-2264

Brata, A. G. (2010). Vulnerability of urban informal sector: Street vendors in Yogyakarta, Indonesia. Theoretical and Empirical Researches in Urban Magagement, 5(14), 47-58. https://mpra.ub.uni-muenchen.de/12541/

Central Bureau of Statistics (CBS). (2008). Nepal labor force survey 2008. http://cbs.gov.np/sectoral_statistics/ poverty/nepal_labor_force_survey_report_2008

Central Bureau of Statistics (CBS). (2011). Poverty in Nepal. CBS.

Chauke, P. K., Munzhelele, R., \& Maiwashe, A. (2015). Some factors impacting on street sellers' ability to generate above poverty line income in Vhembe district, South Africa: Logistic regression approach. Journal of Social Sciences, 44(1), 8-14.https://doi.org/10.1080/09718923.2015.11893452

Cross, J.C. (2000). Street vendors and post modernity: Conflict and compromise in global economy. International Journal of Sociology and Social Policy, 20(1/2), 29-51. http://doi.org/10.1108/01443330010789061

Devlin, R. T. (2011). An area that governs itself: Informality, uncertainty and the management of street vending in New York City. Planning Theory, 10(1), 53-65. .https://doi.org/10.1177/1473095210386070

Kathuria, V., \& Raj, R. S. N. (2015). Do informal sector wages explain rural poverty? Evidence from India. Journal of Poverty, 20(1), 1-29. https://doi.org/10.1080/10875549.2015.1094762

Kusakabe, K. (2006). On the borders of legality: A review of studies on street vending in Phnom Penh, Cambodia. ILO.

Martinez, L., Short, J. R., \& Estrada, D. (2017). The urban informal economy: Street vendors in Cali, Colombia. Cities, 66, 34-43. https://doi.org/10.1016/j.cities2017.03.010

Mazhambe, A. K. (2017). Assessment of contribution of street vending on Zimbabwe economy: A case of street vendors in Harare CBD. IOSR Journal of Business and Management, 19(9), 91-100. http://www. iosrjournals.org/iosr-jbm/papers/Vol19-issue9/Version-1/J19090191100.pdf

National Planning Commission (NPC). (2019). Fifteenth plan (2019/20-2023/24): Approach paper. NPC. https:// www.npc.gov.np/images/category/15th_Plan_Approach_Paper2.pdf

Onodugo, V. A., Ezeadichie, N. H., Onwuneme, C. A., \& Anosike, A. E. (2016). The dilemma of managing the challenges of street vending in public spaces: The case of Enugu city, Nigeria. Cities,59, 95-101. http:// dx.doi.org/10.1016/j.cities.2016.06.001

Roever, S. (2014). Informal Economy Monitoring Study Sector Report: Street Vendors. WIEGO.

Truong, V. D. (2018). Tourism, poverty alleviation and informal economy: The street vendors of Hanoi, Vietnam. Tourism Recreation Research, 43(1), 52-67. https://doi.org/10.1080/02508281.2017.137056

Women in Informal Employment: Globalization and Organizing (WIEGO). (2014). Empowering Informal Workers, Securing Informal Livelihoods. http://wiego.org/informal-economy/occupational-groups/streetvendors

Yatmo, Y. A. (2008). Street vendors as out of place urban elements. Journal of Urban Design, 13(3), 387-402. http://dx.doi.org/10.1080/13574800802320889 